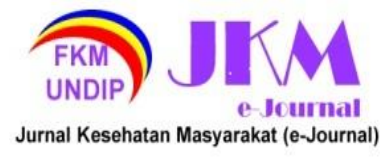

JURNAL KESEHATAN MASYARAKAT (e-Journal)

Volume 10, Nomor 1, Januari 2022

ISSN: 2715-5617 / e-ISSN: 2356-3346

http://ejournal3.undip.ac.id/index.php/jkm

\title{
FAKTOR-FAKTOR YANG MEMPENGARUHI BURNOUT PADA TENAGA KESEHATAN INSTALASI PELAYANAN RADIOLOGI DAN KEDOKTERAN NUKLIR RSUPN CIPTO MANGUNKUSUMO TAHUN 2021
}

\author{
Dita Ayu Astuti ${ }^{1 *}$,Ade Heryana ${ }^{1}$, Anggun Nabila ${ }^{1}$, Devi Angeliana Kusumaningtiar ${ }^{1}$ \\ ${ }^{1}$ Program Studi Kesehatan Masyarakat, Fakultas Ilmu-Ilmu Kesehatan Universitas EsaUnggul \\ *Corespondance author: ditaayuastuti17@gmail.com
}

\begin{abstract}
Health workers are workers who play an important role in hospitals, with daily work dealing with patients. Burnout syndrome is often found in professions that are human service, such as health workers. Burnout is exhaustion both physically, emotionally and mentally as a result of long-term involvement in situations with emotional demands. The purpose of this study was to determine the factors that influence burnout of health workers at the Radiology and Nuclear Medicine Service Installation at Cipto Mangunkusumo General Hospital. The type of research used is cross sectional with a quantitative approach. The study was conducted in July-September 2021. The population and sample were 66 health workers with total sampling method. Data analysis was carried out using univariate and bivariate tests using the chi-square statistical test with $=0.05$. The conclusion from the results of this study is that health workers experienced high burnout by 36 pople (57,1\%), 27 people low burnout (42,9\%), health workers with a working period of 5 years 53 people (84.1\%), years of service $<5$ years 10 people $(15.9 \%)$, very high workload 33 people (52.4\%), high workload 23 people (36.5\%), low workload 7 people $(11.1 \% \%)$, low social support 40 people (63.5\%), and high social support 23 people $(36.5 \%)$. Based on bivariate analysis, it was found that there was a relationship between burnout and workload ( $p$-value $=0.028$, with $P R=2.563$ ). The risk factors for burnout of health workers in this study were years of work, workload, and social support
\end{abstract}

Keywords: Burnout, years of service, workload, social support, health workers

\section{PENDAHULUAN}

Tenaga kesehatan memiliki tanggung jawab yang tinggi karena memiliki pekerjaan yang bersifat human service atau memberikan pelayanan kepada masyarakat yang dituntut untuk memiliki keterampilan yang baik dalam bidang kesehatan. Tanggung jawab dan tuntutan pekerjaan yang banyak dapat berpotensi menjadi stresor bagi perawat. Stresor yang terjadi secara terus menerus dan tidak mampu diadaptasi oleh individu akan menimbulkan beberapa gejala yang disebut dengan burnout syndrome. Burnout syndrome adalah suatu kumpulan gejala fisik, psikologis dan mental yang bersifat destruktif akibat dari kelelahan kerja yang bersifat monoton dan menekan. Burnout syndrome memiliki tiga dimensi, yaitu emotional and physicalexhaustion (keterlibatan emosi yang menyebabkan energi dan sumber-sumber dirinya terkuras oleh satu pekerjaan), depersonalization (sikap dan perasaan negatif terhadap pasien atau orang lain), dan perceive inadequacy of professional accomplishment (penilaian diri negatif dan perasaan tidak puas dengan performa pekerjaan). ${ }^{1}$ Burnout syndrome banyak ditemukan pada profesi yang bersifat human service

Pada profesi tertentu tingkat burnout yang dialami lebih tinggi dibandingkan dengan pekerjaan yang lain. Menurut penelitian Putnik dan Houkes (2011) bahwa burnout dominan paling banyak dialami oleh profesi tenaga kesehatan dan sektor pendidikan. Sebagaimana diketahui, kedua sektor pekerjaan tersebut bersifat human service. Burnout syndrome banyak ditemukan pada profesi yang bersifat human service (pelayanan manusia) seperti tenaga kesehatan medis maupun non medis, polisi, konselor, dan pekerja social. ${ }^{2}$ Burnout sebenarnya terbentuk oleh ketidakseimbangan antara tuntutan pekerjaan dengan kemampuan individu. Burnout merupakan perubahan sikap dan perilaku dalam bentuk reaksi menarik diri secara psikologis dari pekerjaan, seperti menjaga jarak dari orang lain maupun bersikap sinis dengan mereka, membolos, sering terlambat dan keinginan pindah kerja sangat kuat. ${ }^{3}$

Burnout merupakan sindrom yang terdiri dari tiga dimensi, yaitu kelelahan emosional pada dimensi ini akan muncul perasaan frustasi, putus asa, tertekan dan terbelenggu oleh pekerjaan; dimensi kedua depersonalisasi pada dimensi ini akan muncul sikap negatif, kasar, menjaga jarak dan tidak peduli dengan lingkungan sekitar dan ketiga dimensi reduced personal accomplishment atau rendahnya penghargaan diri. Burnout adalah sindrom psikologis yang muncul sebagai respon yang berkepanjangan terhadap stressor interpersonal kronis di tempat kerja. $^{4}$

Peraturan Menteri Kesehatan Tahun 1988 No.159b/Men-Kes/KesJII/1988 Bab II pasal 3 rumah 


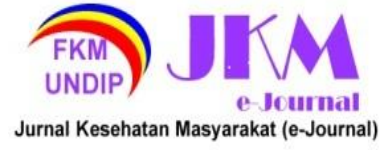

sakit dibagi menjadi dua berdasarkan status kepemilikannya, yaitu rumah sakit pemerintah dan rumah sakit swasta. Berdasarkan Iingkungan rumah sakit yang berbeda status kepemilikan ini terdapat keragaman aspek yang muncul dalam melaksanakan pelayanan yang diberikan oleh tenaga kesehatan kepada pasiennya. Hasil penelitian Windayanti dan Cicilia Yetti Pr dengan total 160 responden, menunjukkan bahwa rata-rata skor emotional exhaustion pada perawat rumah sakit pemerintah lebih besar dibandingkan dengan rata-rata perawat rumah sakit swasta $(29,51>28,1 \quad 0)$, rata-rata skor depersonalization pada perawat rumah sakit pemerintah lebih besar dibandingkan dengan raia-rata perawat rumah sakit swasta $(10,26>9,32)$. Dan ratarata skor perceive inadequacy of professional accomplishment pada perawat rumah sakit pemerintah lebih besar dibandingkan dengan rata-rata perawat rumah sakit swasta $(24,21>21,34){ }^{5}$

Untuk mengetahui tingkat burnout yang terjadi, peneliti melakukan studi awal yang telah dilakukan pada 10 orang tenaga kesehatan di Instalasi Pelayanan Radiologi dan Kedokteran Nuklir RS Cipto Mangunkusumo dengan menggunakan kuisioner MBIHSS (Maslach Burnout Inventory - Human Resource Service) dengan 22 pertanyaan yang di kelompokkan ke dalam 3 dimensi didapat didapat sebanyak $70 \%$ mengalami burnout tinggi, $30 \%$ mengalami burnout rendah. Dimana burnout menjadi variabel dependen dan masa kerja, beban kerja, serta dukungan sosial sebagai variable independen. Gambaran dari 10 tenaga kesehatan, ditinjau dari usia sebesar 60 $\%$ berusia tua ( $\geq 40$ tahun), ditinjau dari masa kerja sebanyak 70 $\%$ tenaga kesehatan mempunyai masa kerja $\geq 5$ tahun, dan ditinjau dari jenis kelamin $60 \%$ terdiri dari wanita. Selain melalui kuesioner, peneliti juga melakukan studi wawancara dengan tenaga kesehatan. Berdasarkan PJ SDM Instalasi Pelayanan Radiologi dan Kedokteran Nuklir RS Cipto Mangunkusumo (Penanggung Jawab Sumber Daya Manusia) dikatakan bahwa banyak tenaga kesehatan yang datang tidak tepat waktu, mengajukan cuti tanpa alasan yang jelas, dan terjadi KTD (Kejadian Tidak Diinginkan) yang dilakukan oleh radiografer.

Berdasarkan hasil observasi di Instalasi Pelayanan Radiologi dan Kedokteran Nuklir RS Cipto Mangunkusumo, lamanya masa kerja menjadi salah satu faktor lain yang dapat menyebabkan burnout di tempat kerja, dimana orang yang telah lama bekerja namun kurangnya promosi jabatan menyebabkan banyak tenaga kesehatan yang merasa jenuh dan stress dengan jabatan menetap yang menyebabkan penghasilan tidak ada peningkatan. Dari data TMT (Terhitung Mulai Tanggal) mayoritas tenaga kesehatan sudah bekerja $\geq 5$ tahun masa kerja. Dengan kurangnya promosi jabatan, menyebabkan karir stuck pada 1 titik. Banyaknya masalah yang sudah terselesaikan, tekanan-tekanan yang ada, dan pengalaman kerja seharusnya mendukung tenaga kesehatan untuk dapat meningkatkan karirnya.

Salah satu faktor lainnya yaitu beban kerja, Setiap instansi kesehatan tentu selalu berusaha untuk meningkatkan performa karyawannya, dengan harapan dapat memberikan pelayanan terbaik, meningkatkan mutu pelayanan dan kepuasan pasien. Setiap instansi atau perusahaan menginginkan karyawan yang multitasking, atau yang bersedia melakukan tugas yang tidak tercantum dalam deskripsi pekerjaan mereka tanpa adanya rasa tekanan. Namun dalam realitanya, tingginya beban kerja yang dialami karyawan berdampak pada timbulnya burnout. Ketidakseimbangan antara beban kerja dan jumlah tenaga kesehatan menyebabkan overload beban kerja. Beban kerja yang tinggi, berdampak pada penurunan kepuasan kerja karena tidak sesuai harapan pekerja dengan ketentuan yang ditetapkan oleh instansi.

Dukungan sosial dari lingkungan sangat mempengaruhi burnout. Dukungan sosial merujuk pada kenyamanan, kepedulian, tenggang rasa, atau segala bentuk bantuan lainnya yang diterima dari orang lain atau kelompok, atasan terhadap bawahan, terhadap teman sejawat, atau rekan kerja lain profesi. Tenaga kesehatan dengan profesi spesifik lebih sering berkumpul hanya dengan teman sejawat. Jarang berkomunikasi, bersosialisasi dan berbaur dengan pekerja lain.

Dampak dari burnout terhadap individu menyebabkan tingginya jumlah absensi meningkat, meningkatnya turnover pegawai, dan menurunya produktivitas kerja. Tidak hanya terhadap individu, tetapi berdampak juga terhadap instansi terkait. Sangat terlihat dengan menurunnya hasil kerja, meningkatnya komplain pasien, dan adanya KTD (Kejadian Tidak Diharapkan).

\section{METODE PENELITIAN}

Penelitian ini dilakukan untuk menganalisis Faktor-Faktor yang Berhubungan Dengan Burnout Tenaga Kesehatan di Instalasi Pelayanan Radiologi dan Kedokteran Nuklir RSCM Tahun 2021. Penelitian dilakukan mulai bulan Juli - September Tahun 2021 di Instalasi Pelayanan Radiologi dan Kedokteran Nuklir RSUPN Cipto Mangunkusumo menggunakan Kuisioner google form yang disebarkan melalui aplikasi WhattApp. Penelitian ini dilakukan menggunakan jenis metode penelitian kuantitatif dengan desain penelitian Cross Sectional dilakukan mulai bulan Juli - September Tahun 2021. Burnout 


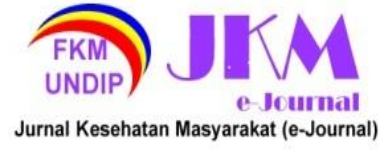

menjadi variabel dependen dan masa kerja, beban kerja, serta dukungan sosial sebagai variable independen.

Berdasarkan uji Komogorov variable burnout dan dukungan sosial menggunakan cut of point median karena hasil tidak normal. Hasil uji validitas menggunakan uji product moment dan uji reliabilitas menggunakan Cronbrach Alpha menunjukkan variable yang diuji valid dan reliabel. Pengolahan data dilakukan dengan menggunakan software computer yaitu aplikasi statistik. Analisis univariat bertujuan
JURNAL KESEHATAN MASYARAKAT (e-Journal)

Volume 10, Nomor 1, Januari 2022

ISSN: 2715-5617 / e-ISSN: 2356-3346

http://ejournal3.undip.ac.id/index.php/jkm

Tabel 1. Distribusi frekuensi Burnout, Masa Kerja, Beban Kerja, dan Dukungan Sosial Tenaga Kesehatan Instalasi Pelayanan Radiologi dan Kedokteran Nuklir RSUPN Cipto Mangunkusumo Tahun 2021 Variabel

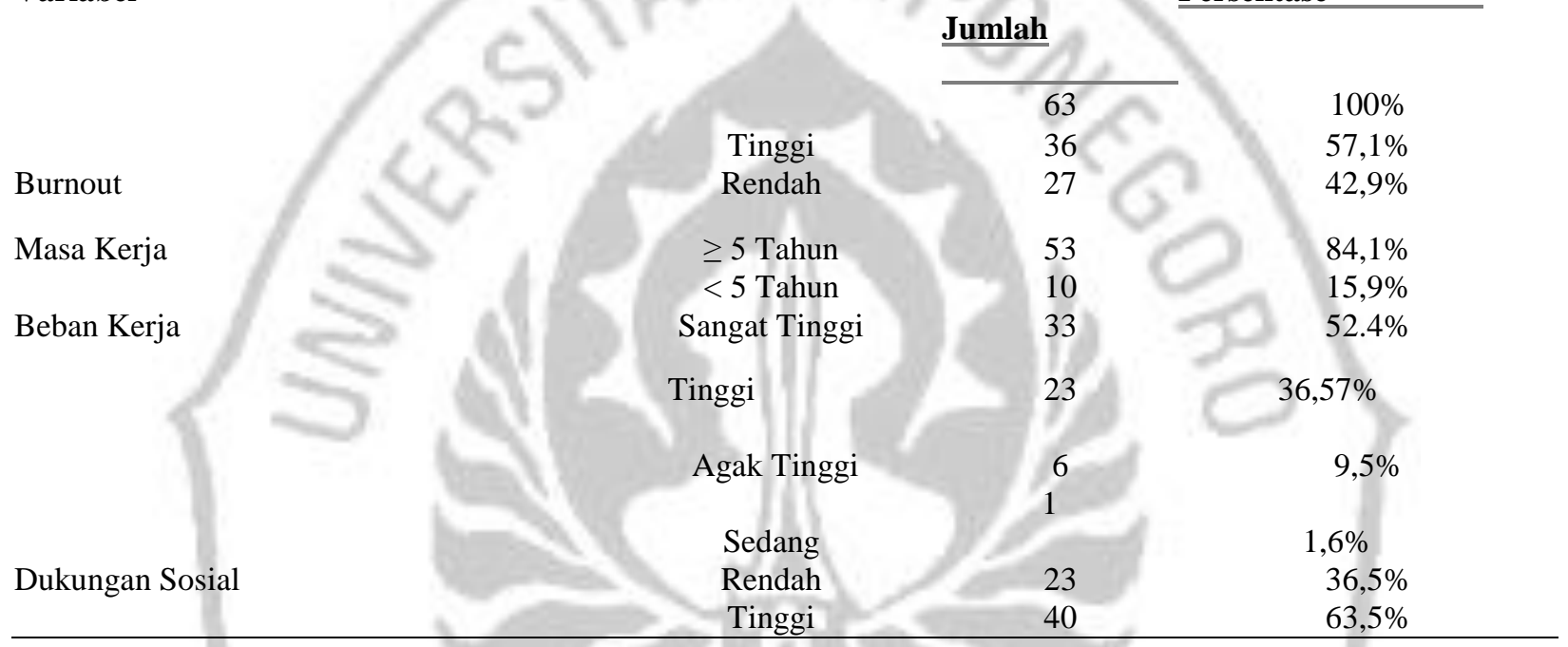

Berdasarkan tabel 1 hasil penelitian terhadap 63 responden. Berdasarkan hasil data diatas yang diolah menggunakan SPSS didapatkan sebanyak burnout tinggi sebesar 36 orang $(57,1 \%)$, burnout rendah 27 orang $(42,9 \%)$, tenaga kesehatan dengan masa kerja $\geq 5$ tahun 53 orang $(84,1 \%)$, masa kerja $<5$ tahun 10 orang $(15,9 \%)$, beban kerja sangat tinggi 33 untuk memperoleh gambaran masa kerja, beban kerja, dukungan sosial terhadap burnout tenaga kesehatan Instalasi Pelayanan Radiologi dan kedokteran Nukli. Analisis bivariat dilakukan menggunakan table kontigensi $2 \times 2$, uji chi square untuk mengetahui hubungan antara variabel independen (masa kerja, beban kerja, dukungan sosial) dengan variabel dependen (burnout).

\section{HASIL PENELITIAN}

Analisis Univariat

Tabel 2. Uji Statistik factor-faktor yang mempengaruhi burnout Tenaga Kesehatan Instalasi Pelayanan Radiologi RSUPN Cipto Mangunkusumo Tahun 2021

\begin{tabular}{|c|c|c|c|c|c|c|c|c|c|}
\hline \multirow[b]{2}{*}{$\begin{array}{l}\text { Variabel } \\
\text { Independen }\end{array}$} & \multirow[b]{2}{*}{ Kategori } & & Burnou & 1 & 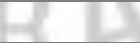 & \multicolumn{2}{|l|}{ Total } & \multirow[b]{2}{*}{$\begin{array}{c}p- \\
\text { value }\end{array}$} & \multirow[b]{2}{*}{$\begin{array}{c}\text { PR } \\
(95 \% \mathrm{CI})\end{array}$} \\
\hline & & \multicolumn{2}{|l|}{$\begin{array}{l}\text { Burnout } \\
\text { Tinggi }\end{array}$} & $\begin{array}{l}\text { Burnout } \\
\text { Rendah }\end{array}$ & $\begin{array}{l}\text { Persepsi } \\
\text { Positif } \\
\end{array}$ & 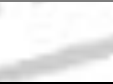 & & & \\
\hline Masa Kerja & $\geq 5$ Tahun & 22 & $41,5 \%$ & 31 & $58,5 \%$ & 53 & $100 \%$ & 0,733 & 0,830 \\
\hline & $<5$ Tahun & 5 & $50,0 \%$ & 5 & $50,0 \%$ & 10 & $100 \%$ & & $\begin{array}{l}(0,413- \\
1,677)\end{array}$ \\
\hline Beban & Tinggi & 41 & $73,2 \%$ & 15 & $26,8 \%$ & 56 & $100 \%$ & 0,028 & 2,563 \\
\hline Kerja & Tidak Tinggi & 2 & $28,6 \%$ & 5 & $71,4 \%$ & 7 & $100 \%$ & & $\begin{array}{l}(0,786- \\
8,356)\end{array}$ \\
\hline Dukungan & Tinggi & 10 & $43,5 \%$ & 33 & $56,5 \%$ & 23 & $100 \%$ & 1,000 & $\begin{array}{c}1,023(0,568- \\
1844)\end{array}$ \\
\hline
\end{tabular}




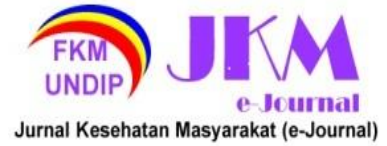

Rendah
JURNAL KESEHATAN MASYARAKAT (e-Journal)

Volume 10, Nomor 1, Januari 2022

ISSN: 2715-5617 / e-ISSN: 2356-3346

http://ejournal3.undip.ac.id/index.php/jkm
Berdasarkan tabel 2 hasil analisis bivariat pada uji chi square menunjukan bahwa ada hubungan antara burnout tenaga kesehatan dengan beban kerja ( $p$ value $=0,028, \mathrm{PR}=2,563$ ) tenaga kesehatan dengan beban kerja tinggi cenderung beresiko 2,563 kali mengalami burnout dibandingkan tenaga kesehatan dengan beban kerja tidak tinggi. Tidak ada hubungan antara burnout tenaga Kesehatan dengan masa kerja ( $p$ value $=0,733, \mathrm{PR}=0,830)$, dan dukungan sosial $(p$ value $=1,000, \mathrm{PR}=1,023$ ) tenaga kesehatan dengan dukungan sosial rendah cenderung beresiko 1,023 kali mengalami burnout dibandingkan tenaga kesehatan dengan dukungan sosial tinggi.

\section{PEMBAHASAN}

Gambaran Burnout Tenaga Kesehatan Instalasi Pelayanan Radiologi dan Kedokteran Nuklir RSCM Tahun 2021

Berdasarkan hasil penelitian yang dilakukan pada 63 tenaga kesehatan Instalasi Pelayanan Radiologi dan Kedokteran Nuklir RSCM Tahun 2021, menggunakan Kuisioner MBI-HSS mayoritas tenaga kesehatan mengalami burnout tinggi yaitu sebesar $57,1 \%$ mengalami burnout tinggi dan 42,9\% mengalami burnout rendah. Sebagian besar dari responden menyatakan bahwa merasa orang-orang yang bekerja di rumah sakit menyusahkannya, berdasarkan hasil tabulasi dengan usia adalah kelompok usia 31 tahun - 40 tahun karena kelompok usia tersebut dalam kesehariannya harus membimbing usia lebih muda yang masa kerjanya $<5$ tahun, dan menghadapi sikap kerja tenaga kesehatan senior yang anti pati karena mendekati masa pensiun. Dominan kelompok usia 31 tahun - 40 tahun tenaga kesehatan yang merasa lelah ketika bangun pagi karena membayangkan beratnya pekerjaan yang harus di jalani karena usia tersebut dimana pekerja ditahap menengah, dan sebagian besar tenaga kesehatan dengan profesi dokter dan radiografer selalu merasa sangat lelah diakhir jam dinas,

Menurut Maslach, menyatakan burnout tinggi dapat di definisikan merupakan kelelahan baik secara fisik, emosional dan mental sebagai akibat dari keterlibatan diri dalam jangka waktu yang panjang terhadap situasi dengan tuntutan emosional. ${ }^{1}$ Cary Cherniss yang mengatakan bawha dampak burnout sebagai perubahan sikap dan perilaku dalam bentuk reaksi menarik diri secara psikologis dari pekerjaan, seperti menjaga jarak dengan klien maupun bersikap sinis dengan mereka, membolos, sering terlambat, dan keinginan pindah kerja yang kuat .

RSUPN Cipto Mangunkusumo merupakan
Rumah Sakit rujukan Nasional dan merupakan Rumah Sakit Pendidikan di Jakarta.Tenaga kesehatan dituntut untuk bekerja secara loyalitas dan profesional. Burnout yang terjadi pada tenaga kesehatan sangat penting untuk dilakukan evaluasi rutin secara berkala, hal ini dikarenakan tenaga kesehatan memegang peranan sangat penting dalam proses pelayanan di rumah sakit. Tenaga kesehetan yang mengalami burnout yang terlalu tinggi dapat mempengaruhi kemampuan individu dalam menghadapi lingkungan kerja, sehingga berkembang berbagai akibat baik mental maupun fisik yang sangat dapat mengganggu proses pelayanan.

Kondisi ini terjadi karena tenaga kesehatan lebih banyak menggunakan tenaganya untuk melawan burnout yang dialami dari pada melakukan pekerjaannya. Berdasarkan observasi burnout tinggi pada tenaga kesehatan dapat berakibat mengalami rasa lelah yang berkepanjangan, kurangnya konsentrasi, dan hilangnya motivasi kerja yang dapat menimbulkan semakin meningkatnya waktu tunggu pasien yang membuat pelayanan menjadi buruk, Kejadian Tidak Diharapkan (KTD) atau insiden sentinel yang seharusnya $0 \%$ menjadi ada atau meningkat yang dapat berakibat fatal terhadap pasien, dan menurunnya sikap saling membantu terhadap sesama rekan kerja. Dampak-dampak ini juga dapat berakibat pada meningkatnya jumlah komplain pasien.

Hubungan Antara Masa Kerja dengan Burnout tenaga kesehatan Instalasi Pelayanan Radiologi dan Kedokteran NuklirTahun 2021

Berdasarkan hasil penelitian didominasi oleh tenaga kesehatan dengan masa kerja $\geq 5$ tahun dan sebagian besar merasa burnout tinggi sebesar 53 orang $(84,1 \%)$. Berdasarkan hasil analisis chi square diketahui tidak ada hubungan antara variable masa kerja dengan burnout. RSCM merupakan salah satu rumah sakit pemerintah dan kebanyakan tenaga kesehatan merupakan Aparatur Sipil Negara (ASN) dengan masa bakti sampai dengan usia 60 tahun. Burnout yang terjadi pada tenaga kesehatan dengan masa kerja $\geq 5$ tahun bisa diakibatkan karena profesi responden yang berhubungan langsung dengan pasien sehingga dituntut untuk cepat tanggap, dan harus selalu sesuai dengan prosedur yang ada. Berdasarkan hasil tabulasi antara masa kerja dan profesi tenaga kesehatan, sebagian besar profesi dokter dan radiografer yang paling tinggi mengalami burnout tinggi dengan masa kerja $\geq 5$ tahun.

Dari hasil observasi juga didapatkan pegawai yang sudah bekerja $\geq 5$ tahun merasa mulai jenuh 


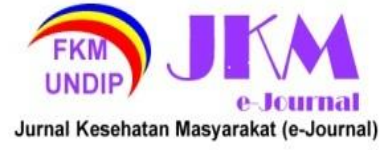

dengan pekerjaan karena harus menangani pasien yang tidak sedikit, dengan tekanan kerja yang banyak dalam masa waktu yang lama, kurang-nya kesempatan untuk promosi diri, dan adanya prosedur serta aturan yang kaku yang membuat orang merasa terjebak dalam sistem yang tidak adil. Secara teoritis ada hubungan antara masa kerja dengan burnout, namun hasil penelitian menunjukkan tidak ada hubungan antara masa kerja dengan burnout tenaga kesehatan Instalasi Pelayanan Radiologi dan Kedokteran Nuklir RSCM Tahun 2021. Artinya semakin lama masa kerja tenaga kesehatan, tidak ada kaitannya dengan burnout yang dialami.

Menurut Munandar Masa kerja berhubungan dengan stres kerja yang berkaitan dengan dalam menimbulkan burnout dalam bekerja. ${ }^{6}$ Pekerja yang telah bekerja lebih dari lima biasanya biasanya memiliki tingkat burnout yang lebih tinggi dari pekerja yang baru. Masa kerja merupakan ukuran tentang lama waktu atau masa kerja yang telah ditempuhseseorang memahami tugas - tugas suatu pekerjaan dan telah melaksanakan dengan baik. Masa kerja merupakan indikator dari pengalaman kerja. Masa kerja memberi pengaruh positif pada kinerja bila dengan semakin lamanya masa kerja seseorang semakin berpengalaman dalam melaksanakan tugasnya, sebaliknya memberikan pengaruh negatif apabila dengan semakin lamanya masa kerja akan timbul gangguan kesehatan pada pekerja serta timbul kebosanan yang disebabkan oleh pekerjaan yang sifatnya monoton.

Hubungan Antara Beban Kerja dengan burnout tenaga kesehatan Instalasi Pelayanan Radiologi dan Kedokteran NuklirTahun 2021

Berdasarkan hasil penelitian yang telah dilakukan pada 63 tenaga kesehatan didapatkan sebanyak 52,4\% tenaga kesehatan merasa memiliki beban kerja tinggi. Hasil analisis chi square diketahui ada hubungan yang signifikan antara beban kerja dengan burnout tenaga kesehatan. Beban kerja tinggi cenderung $2 \mathrm{kali}$ lebih berpotensi menyebabkan burnout tinggi dibandingkan dengan beban kerja tidak tinggi. Hal ini sejalan dengan penelitian hasil penelitian yang dilakukan oleh (Sari, 2016) terdapat hubungan yang signifikan antara beban kerja tinggi dengan burnout. Selain itu, sebagian besar responden mengalami beban kerja yang tinggi yaitu 38 orang $(71,7 \%)$ dan 15 orang $(28,3 \%)$ mengalami beban kerja sedang. Hasil cross tabulation menunjukkan 5 orang $(9,5 \%)$ responden dengan beban kerja tinggi mengalami burnout syndrome berat.

Dari hasil perhitungan bobot beban kerja yang telah dilakukan pada ke enam indikator beban kerja, diperoleh kebanyakan tenaga kesehatan merasa indikator kebutuhan fisik dan tingkat frustasi merupakan indikator yang paling berpengaruh dalam menyelesaikan pekerjaan. Sedangkan tingkat usaha merupakan indikator yang paling tidak berpengaruh dalam menyelesaikan pekerjaan. Kebutuhan fisik adalah berapa besar aktivitas fisik yang dibutuhkan dalam pekerjaan tenaga kesehatan (contoh: mendorong, menarik, memutar, mengontrol, menjalankan, dan lainnya) karena tenaga kesehatan di Instalasi Pelayanan Radiologi dan Kedokteran Nuklir menangani pasien secara teknisi karena menggunakan alat-alat radiografi yang kesehariannya berhadapan langsung dengan radiasi, dan tingkat usaha adalah seberapa besar usaha yang di keluarkan secara mental dan fisik yang dibutuhkan untuk mencapai level performansi dalam bekerja dan berdasarkan hasil kuisioner sebanyak $52 \%$ tenaga kesehatan yang menyatakan beban kerja sangat tinggi merasakan tidak ada penghargaan atau reward terhadap prestasi kerja.

Beban kerja tenaga kesehatan merupakan bagian dari pengembangan tenaga kesehatan dirumah sakit yang dihitung berdasarkan jumlah waktu yang dibutuhkan untuk memberikan layanan kepada pasien per hari dan jumlah tenaga kesehatan. Beban kerja tenaga kesehatan dipengaruhi oleh kondisi jumlah pasien, jumlah rata-rata jam layanan yang dibutuhkan untuk memberikan pelayanan langsung kepada pasien, serta banyaknya tugas tambahan yang harus dikerjakan oleh waktu kerjanya. Dari hasil observasi, sebagian besar tenaga kesehatan berkerja melebihi dari tugas pokok dan fungsi (Tupoksi) yang ada dan kurangnya SDM sehingga banyak tenaga kerja yang mengerjakan pekerjaan di luar Tupoksi yang sudah tertulis dalam waktu yang lama dan terus-menerus menyebabkan sebagian besar tenaga kesehatan mengalami burnout tinggi.

Berdasarkan masalah diatas maka perlu adanya evaluasi secara rutin dan karena banyaknya pasien sehingga sangat diperlukan penambahan tenaga kesehatan, agar dapat bekerja sesuai dengan tugas pokok dan fungsi (Tupoksi) yang ada di dalam Surat Keputusan (SK) yang berlaku pada setiap individu.

Hubungan antara dukungan sosial dengan burnout tenaga kesehatan Instalasi Pelayanan Radiologi dan Kedokteran NuklirTahun 2021

Berdasarkan hasil penelitian yang dilakukan pada 63 tenaga kesehatan Instalasi Pelayanan Radiologi dan Kedokteran Nuklir didapatkan 40 orang $(63,5 \%)$ tenaga kesehatan mengalami dukungan sosial rendah. Berdasarkan hasil analisa, hasil penelitian dukungan sosial rendah, didominasi karena atasan tidak memberikan kesempatan kepada bawahan untuk mengembangkan potensi diri yang dimiliki, 


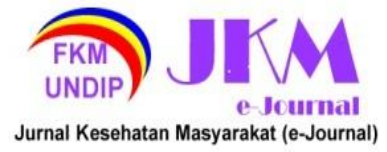

karena banyak tenaga kesehatan dengan masa kerja $\geq$ 5 tahun tidak diberikan kesempatan untuk mengembangkan diri dengan potensi yang dimiliki memakan waktu dan sulitnya pengembangan diri dalam hal pengajuan namun jika tenaga kesehatan mengalami masalah dengan rekan kerja atau teman sejawat, atasan memberikan petunjuk cara penyelesaian masalah tersebut.

Dukungan sosial sebagai informasi dari orang lain yang menggambarkan individu dicintai dan dipedulikan, dihormati dan dihargai, dan bagian dari jaringan komunikasi dan kewajiban bersama. Dukungan rekan kerja adalah bantuan yng diberikan oleh rekan kerja ketika menghadapi masalah, bantuan tersebut berupa informasi baik verbal maupun non verbal.

Dukungan sosial dapat melindungi individu dari gangguan kesehatan mental, seperti burnout. Sedangkan individu yang kurang memiliki dukungan sosial cenderung lebih rentan terkena gangguan fisik dan psikologis. Dukungan sosial dapat diperoleh dari atasan kepada bawahan, teman sebaya, rekan kerja, instistusi kerja, dan lingkungan sekitar.

Berdasarkan masalah diatas perlu ada pengembangan diri seperti diadakan satau pelatihan sesuai dengan kompetensi tenaga kesehatan secara individual, dan Institusi sebaiknya memfasilitasi atau mempermudah para tenaga kesehatan jika membutuhkan pengembangan diri sesuai kompetensi yang ada.

\section{KESIMPULAN}

Berdasarkan hasil penelitian yang telah dilakukan, maka penulis dapat menyimpulkansebagai berikut:

1. Gambaran Distribusi Burnout tenaga kesehatan Instalasai Pelayanan Radiologi dan Kedokteran Nuklir dengan proporsi tertinggi adalah tenaga kesehatan dengan burnout tinggi sebanyak 44 orang $(69,8 \%)$.

2. Gambaran Distribusi Masa Kerja tenaga kesehatan Instalasai Pelayanan Radiologi dan Kedokteran Nuklir dengan proporsi tertinggi adalah tenaga kesehatan dengan masa kerja $\geq 5$ tahun sebanyak 53 orang $(84,1 \%)$.

3. Gambaran Distribusi Beban Kerja tenaga kesehatan Instalasai Pelayanan Radiologi dan Kedokteran Nuklir dengan proporsi tertinggi adalah tenaga kesehatan dengan burnout beban kerja sangat tinggi sebanyak 33 orang $(52,4 \%)$.

4. Gambaran Distribusi Dukungan Sosial tenaga kesehatan Instalasai Pelayanan Radiologi dan Kedokteran Nuklir dengan proporsi tertinggi adalah tenaga kesehatan dengan dukungan sosial rendah sebanyak 40 orang $(63,5 \%)$.

5. Tidak Ada hubungan antara Masa Kerja dengan Burnout Tenaga Kesehatan Instalasai Pelayanan Radiologi dan Kedokteran Nuklir RSUPN Cipto Mangunkusumo Tahun 2021. Nilai PR sebesar 1,195 .

6. Ada hubungan antara Beban Kerja dengan Burnout Tenaga Kesehatan Instalasai Pelayanan Radiologi dan Kedokteran Nuklir RSUPN Cipto Mangunkusumo Tahun 2021. Nilai PR sebesar 2,625 .

7. Tidak Ada hubungan antara Dukungan Sosial dengan Burnout Tenaga Kesehatan Instalasai Pelayanan Radiologi dan Kedokteran Nuklir RSUPN Cipto Mangunkusumo Tahun 2021. Nilai PR sebesar 0,900 .

\section{2.}

\section{SARAN}

Berdasarkan kesimpulan di atas, variable beban kerja yang sangat tinggi mendominasi dan berhubungan mempengaruhi burnout tenaga kesehatan Instalasai Pelayanan Radiologi dan Kedokteran Nuklir RSUPN Cipto Mangunkusumo Tahun 2021. Maka peneliti mengajukan saran, sebagai berikut :

1. Untuk mengurangi beban kerja mental dan beban kerja rasa frustasi, maka disarankan manajemen menerapkan budaya kerja yang lebih menghargai prestasi pekerja sehingga keluhan burnout yang dirasakan pekerja dapat dikurangi

2. Untuk mengurangi keluhan burnout maka disarankan manajemen mengevaluasi dan mengatur kembali beban kerja karyawan agar sesuai dengan Tupoksi yang berlaku

\section{DAFTAR PUSTAKA}

1. Maslach, L. (2008). The Truth About Burnout: How Organizations Cause Personal Stress and What to Do About It. John Wiley \& Sons.

2. Sihotang, I. N. (2004). Burnout Pada Karyawan Ditinjau Dari Persepsi Terhadap Lingkungan Kerja Psikologis Dan Jenis Kelamin. Jurnal PSYCHE, 1(1), 9-17

3. Luh, N., Dian, P., Program, Y. S., S1, S., Stikes, K., \& Usada Bali, B. (2016). Hubungan Beban Kerja Terhadap Burnout Syndrome Pada Perawat Pelaksana Ruang Intermediet Rsup Sanglah. Jurnal Dunia Kesehatan, 5(2), 77069. https://www.neliti.com/publications/77069/

4. Tinambunan, E. (2018). Burnout syndrome pada perawat diruangan rawat inap rumah sakit santa elisabeth medan. Jurnal Keperawatan Priority, l(1), 85-98.

5. Windayanti, \& Prawasti. (2010). Burnout pada 


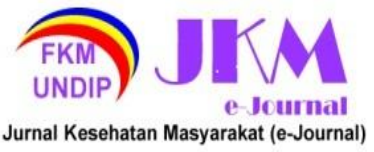

Perawat Rumah Sakit Pemerintah dan Perawat Rumah Sakit Swasta. 127-140.

6. Rezal, F., Munandar, S., Kesehatan, F., Universitas, M., \& Oleo, H. (2017). < $\alpha$ sehingga
JURNAL KESEHATAN MASYARAKAT (e-Journal)

Volume 10, Nomor 1, Januari 2022

ISSN: 2715-5617 / e-ISSN: 2356-3346

http://ejournal3.undip.ac.id/index.php/jkm

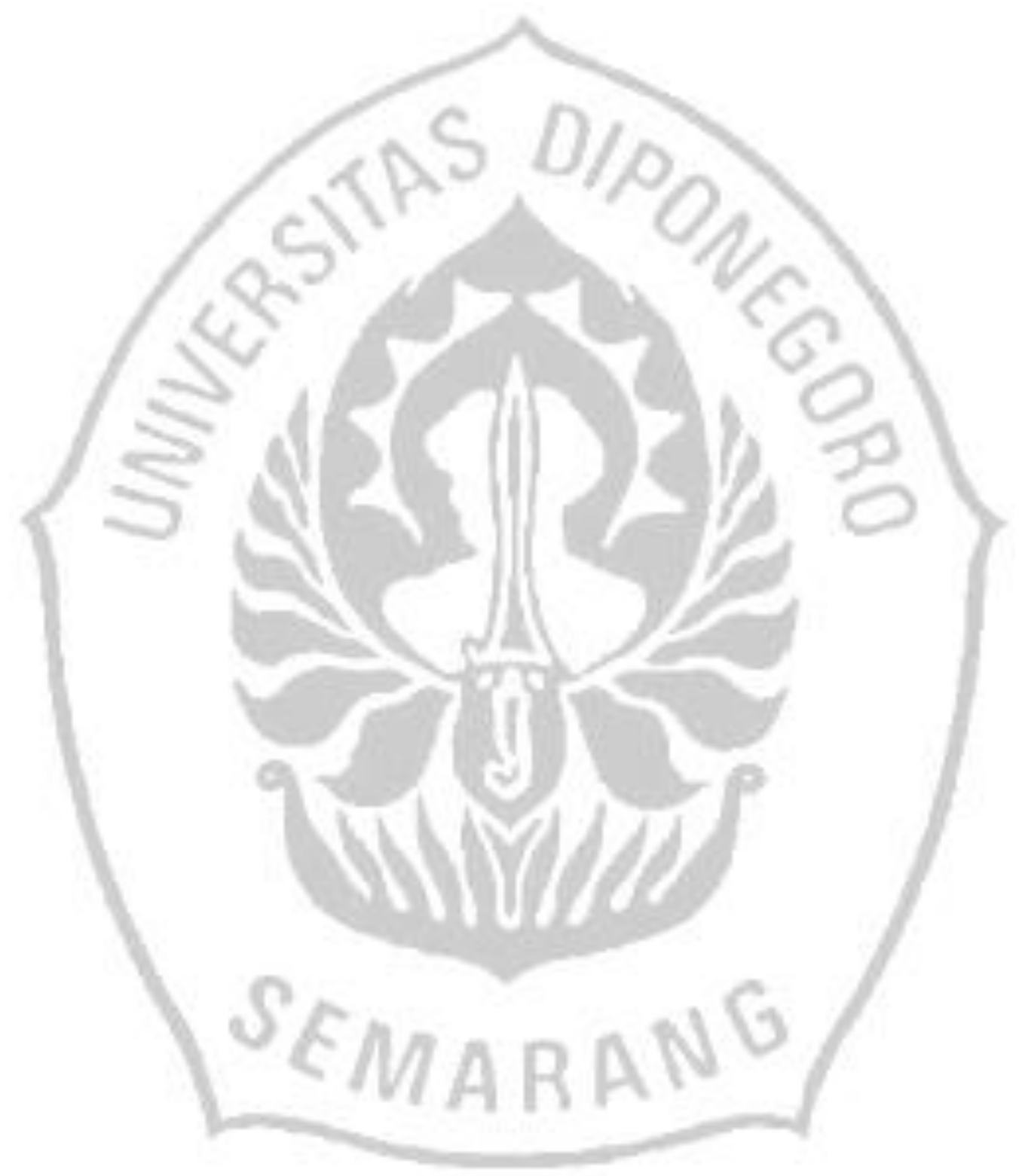

